\title{
PEMANFAATAN SPENT RESOURCES DALAM MENDUKUNG KEGIATAN ECO-ECONOMIC DECOUPLING DI PROVINSI JAWA TENGAH
}

\section{UTILIZATION OF SPENT RESOURCES IN SUPPORT OF ECO-ECONOMIC DECOUPLING IN CENTRAL JAVA}

\author{
Nuril Fikri Aulia \\ Badan Penelitian dan Pengembangan (BPP) Kementrian Dalam Negeri \\ Jl. Kramat Raya No. 132 - Senen, Jakarta \\ No. Telp: 021-3101953 \\ Email:nf_aulia@yahoo.com \\ Dikirim: 14 April 2015 Direvisi: 20 Juni 2015 Disetujui: 20 Agustus 2015
}

\begin{abstract}
Abstrak
Kajian ini dilatarbelakangi oleh pelaksanaan pembangunan yang dilakukan seringkali menimbulkan dampak buruk bagi lingkungan. Dampak buruk tersebut adalah kerusakan lingkungan dan semakin menipisnya ketersediaan sumberdaya yang dapat dimanfaatkan. Untuk mengatasi hal tersebut perlu diupayakan agar pembangunan yang dilaksanakan tetap dapat berjalan, lingkungan tidak rusak, dan ketersediaan sumberdaya tetap terjaga. Salah satu upaya adalah melalui kegiatan eco-economic decoupling dengan pemanfaatan spent resources. Kajian ini bertujuan untuk mengetahui potensi spent resources di Provinsi Jawa Tengah, mengetahui permasalahan dalam pemanfaatan spent resources di Provinsi Jawa Tengah, dan untuk mengetahui dampak pemanfaatan spent resources di Provinsi Jawa Tengah. Metode yang digunakan adalah melalui kajian deskriptif kualitatif. Hasil kajian menunjukkan bahwa Jawa Tengah memiliki potensi eco-economic decoupling yang ditunjukan dengan adanya ketersediaan dan pemanfaatan spent resources. Namun demikian potensi tersebut belum berkembang optimal, karena masih terdapat beberapa kendala dan permasalahan dalam pemanfaatannya. Permasalahan dalam pemanfaatan spent resources antara lain:kurangnya pengetahuan dan pemahaman tentang eco-economic decoupling dan spent resources diantara stakeholders, belum ada kebijakan khusus tentang eco-economic decoupling, kurangnya peran Pemerintah Daerah dalam pemanfaatan spent resources, dan belum adanya sinergitas program dan kegiatan dalam mendukung pemanfaatan spent resources. Pemanfaatan spent resources memberikan dampak positif yaitu pengurangan tekanan terhadap lingkungan dan sumberdaya alam, peningkatan lapangan pekerjaan dan pendapatan masyarakat.
\end{abstract}

Kata Kunci: Pembangunan, Lingkungan, Spent Resources, Eco-Economic Decoupling

\begin{abstract}
Implementation of the development is often cause adverse environmental impacts . Adverse effects are environmental degradation and decreasing avaibility of resources. To overcome this it is necessary that the development can still continue, the environment is not damaged, and the availability of resources is maintained. One effort is through eco-economic decoupling activities with the use of spent resources. The aim of study to determine the potential of spent resources in Central Java, knows the problems in the utilization of spent resources in Central Java, and to determine the impact of the utilization of spent resources in Central Java by a qualitative descriptive method. The results show that in the study have the potential of eco - economic decoupling indicated by the availability of spent resources and had done utilization of spent resources. However, this potential has not been optimally developed, because there are still some problems in its utilization. Problems in the use of spent resources are the lack of knowledge about eco-economic decoupling and spent resources among stakeholder, there is no specific policy on eco - economic decoupling, the lack of Local Government 's role in the utilization of spent resource, and the lack of synergy programs and activities in supporting the utilization of spent resources. Utilization of spent resources have positive impact to reduce pressure on the environment and natural resources, create a new job, and increase incomes for society. Keyword: Development, Environment, Spent Resources, Eco-Economic Decoupling
\end{abstract}

\section{PENDAHULUAN}

Pembangunan dilaksanakan tidak lain adalah untuk menuju kesejahteraan. Tetapi dalam pelaksanaannya selama ini seringkali selain dampak positif terhadap kesejahteraan, terdapat pula dampak lain dari pembangunan tersebut, diantaranya adalah dampak terhadap lingkungan.

Dampak terhadap lingkungan terjadi karena upaya-upaya yang dilakukan dalam melaksanakan pembangunan di berbagai bidang tidak bisa terlepas dari lingkungan. Dari lingkunganlah tersedia 
berbagai sumber daya sebagai penyokong kegiatankegiatan pembangunan. Sumber daya sendiri didefinisikan sebagai sesuatu yang dianggap memiliki nilai ekonomi atau komponen yang diperl ukan untuk aktivitas ekonomi (Nur Bb, Azis 2009) 1).

Ketersediaan sumber daya tidak tak terbatas dalam mendukung upaya pembangunan, sementara kebutuhan kegiatan manusia terhadap sumberdaya semakin meningkat seiring dengan bertambahnya jumlah populasi. Konsumsi energi final Indonesia lainnya terus mengalami kenaikan seiring dengan semakin meningkatnya kegiatan ekonomi di semua sektor baik industri, transportasi, rumah tangga dan komersial. Dengan kenaikan rata-rata $4,7, \%$ per tahun (3,4\% per tahun tanpa biomasa). Berdasarkan wilayahnya, kebutuhan energi menurut skenario BAU masih didominasi oleh Jawa. Pada tahun 2030 kebutuhan energi final di wilayah Jawa mencapai 253,91 juta TOE atau 38,55\% dari total kebutuhan energi final di Indonesia. Salah satu contoh yang menunjukkan fenomena keterbatsan sumberdaya adalah bahwa di Indonesia jumlah masyarakat yang belum mendapatkan akses terhadap listrik masih 87,69 juta penduduk. Keterbatasan infrastruktur domestik menjadi tantangan dan permasalahan dalam memenuhi kebutuhan energi domestik. ${ }^{2)}$ Untuk contoh kebutuhan salah satu sumberdaya dalam hal ini energi di lokasi kajian yaitu provinsi Jawa Tengah, Hasil proyeksi jumlah total pelanggan dan kebutuhan energi listrik Provinsi Jawa Tengah dari tahun 2009 hingga 2013 meningkat disetiap tahunnya dengan rata-rata pertumbuhan jumlah pelanggan sebesar $0.059 \%$, dan pertumbuhan kebutuhan energi listrik sebesar $2.04 \%{ }^{3)}$.

Selain menghadapi kebutuhan terhadap sumberdaya dan keterbatasan sumberdaya, dari berbagai kegiatan hasil pembangunan, selain mengahasilkan produk utama, tentu menghasilkan produk sampingan yang sebelumnya orang terbiasa menyebutnya limbah tetapi dalam tulisan ini akan diperkenalkan sebagai konsep spent resources (sumberdaya yang telah tergunakan). Produk sampingan tersebut jika tidak mendapat penanganan khusus dapat menimbulkan beban terhadap lingkungan. Data menunjukkan jumlah industri, baik kategori besar, menengah, maupun kecil, di Jawa Tengah mencapai 645.212 unit. Dari jumlah tersebut,
0,05 persen di antaranya memberikan dampak pencemaran lingkungan limbah cair sebesar 5 meter kubik per hari. Setiap tahun limbah cair yang dibuang oleh industri-industri mencapai 1,68 juta meter kubik. Bukan hanya limbah, volume jumlah sampah di Jawa Tengah juga terus menerus mengalami kenaikan. Data Pemerintah Provinsi Jawa Tengah menunjukkan bahwa volume timbunan sampah pada 2007 yang dihasilkan masyarakat Jawa Tengah mencapai 48.570 meter kubik per hari. Jumlah tersebut naik pada 2008 menjadi 49.316 meter kubik per hari ${ }^{4)}$.

Upaya pembangunan dalam rangka mencapai kesejahteraan tentu saja harus terus berjalan dengan meminimalisir sedapat mungkin dampak buruk yang ditimbulkannya terhadap lingkungan dan semaksimal mungkin melakukan penghematan terhadap pemakaian sumber daya yang digunakan. Salah satu upaya untuk menyelaraskan antara kegiatan pembangunan yang bernilai ekonomi dan lingkungan adalah melalui kegiatan eco-economic decoupling melalui pemanfaatan spent resources.

Konsep spent resources sebagai bagian dari kegiatan eco-economic decoupling dapat dijelaskan sebagai berikut ${ }^{5 \text { dan } 6)}$ :

Pada proses produksi konvensional, hasil samping dari produksi biasanya langsung dianggap sebagai limbah, sehingga tidak diperhitungkan sebagai produk yang mempunyai nilai ekonomi. Setelah limbah-limbah terakumulasi dan akhirnya menimbulkan pencemaran, timbullah kesadaran baru mengenai pentingnya menjaga atau merawat kualitas lingkungan hidup. maka lahirlah pemikiran mengenai pentingnya merawat kualitas lingkungan agar lingkungan dapat mendukung kehidupan diatasnya secara berkelanjutan.

Pada Gambar 1 diperlihatkan bahwa proses produksi sebelum terjadinya akumulasi limbah yang kemudian menimbulkan pencemaran yang berakibat pada turunnya kualitas lingkungan, melahirkan kebijakan yang disebut sebagai : “yang menimbulkan pencemaran harus/wajib menanggulangi” atau prinsip "polluters pay”. Pada era ini produk samping dari suatu proses produksi yang tidak bernilai ekonomi masih disebut sebagai "limbah industri", yang seringkali dibuang begitu saja. Pada saat jumlahnya masih sedikit, maka dampak lingkungannya tidak atau belum dirasakan, karena

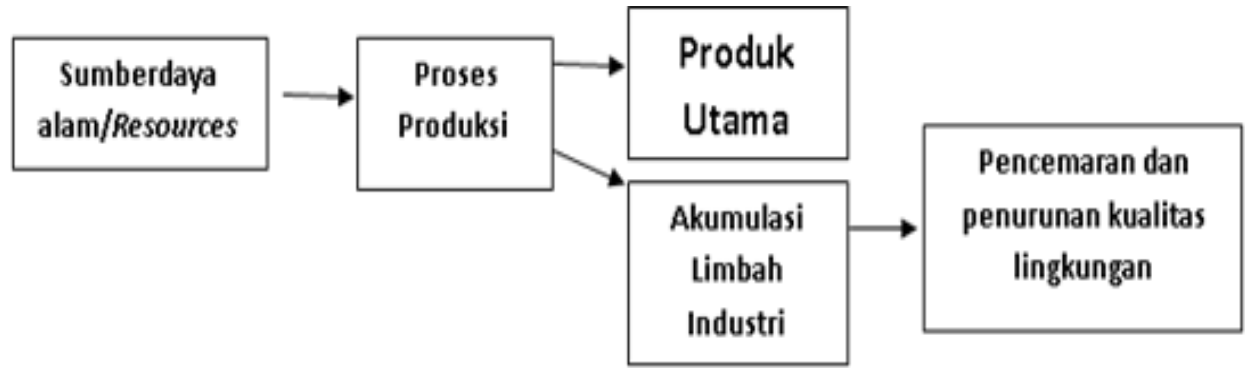

Gambar 1. Proses Produksi Biasa (Bussines as Usual) dan Dampaknya 
alam masih sanggup meregenerasi "limbah-limbah" tersebut, sehingga masih belum menyebabkan tempat-tempat pembuangan limbah itu seperti sungai-sungai, danau, laut atau lahan darat yang menjadi tempat permukiman belum dianggap tercemar.

Pada era polluter pay, banyak para produsen yang mengeluh mengenai penurunan keuntungan, bahkan ada yang nyaris ditutup, karena tidak mampu membangun pengolah limbah.

Pada era ini pula terjadinya relokasi industri antar negara, sebagian juga disebabkan karena ada negara-negara yang tidak ketat dalam menggariskan kebijakan lingkungan hidupnya, dalam arti baku mutu lingkungan masih cukup longgar sehingga biaya untuk mengatasi persoalan lingkungan hidup masih dalam keadaan terjangkau dalam arti keuntungan dikurangi biaya lingkungan masih cukup dianggap tetap memberikan keuntungan yang memadai, dengan rumus :

Net Profit (NP) $=\mathrm{P} x \mathrm{~V}-\mathrm{C}-\mathrm{BL}-\mathrm{Tax}-$ lain-lain, Dimana :

$\mathrm{P}=$ price/harga

$\mathrm{V}=$ Volume penjualan

$\mathrm{C}$ = biaya produksi (termasuk biaya bahan

baku/SDA/resources)

$\mathrm{BL}$ = biaya lingkungan

Tax $=$ pajak-pajak

Lain-lain = keamanan dll.

Selama net profit masih positif, sekalipun ada biaya lingkungan, maka untuk melangsungkan produksi masih dianggap layak. Tetapi bila adanya penambahan BL, kemudian Net Profit menjadi negatif, maka tentu usaha harus ditutup. Keadaan seperti ini yang dicari jalan keluarnya, sehingga lahirlah berbagai jenis solusi, seperti konsep-konsep produksi bersih, pengurangan material melalui perbaikan proses produksi (waste reduction atau waste minimization) dan akhirnya lahir pemikiran tentang $3 \mathrm{R}$, dan sekarang berkembang menjadi $4 \mathrm{R}$.

Pada tahap yang paling awal, di berbagai daerah, produsen yang dalam proses produksi masih menghasilkan limbah, disarankan agar produsen mengolah limbah-limbah tersebut sehingga setelah memenuhi baku mutu lingkungan, baru bisa dibuang keluar pabrik dan tidak terjadi akumulasi limbah dan akhirnya tidak mencemari lingkungan. Kewajiban seperti ini selalu dianggap oleh produsen sebagai beban tambahan usaha, karena produsen harus membangun instalasi pengolah limbah sebelum limbah dibuang ke udara atau ke sungai atau ke lokasi pembuangan akhir (TPA). Kewajiban ini seringkali tidak dipenuhi oleh para produsen, karena dianggap hanya sebagai cost atau biaya tambah proses produksi yang pada gilirannya akan mengurangi profit.

Dalam perkembangan berikutnya, lahirlah konsep pembangunan berkelanjutan (sustainable development) yang esensinya adalah memunculkan berbagai upaya, tentang bagaimana pertumbuhan ekonomi dapat berlangsung, agar disamping mampu menopang pertumbuhan kehidupan di atasnya sebagai akibat pertumbuhan jumlah penduduk, tetapi tidak menimbulkan dampak negatif terhadap kualitas lingkungan hidup.

Pada Gambar 2 dapat dijelaskan bahwa terdapat perbedaan sistim produksi dalam konsep eco-economic decoupling dengan sistim berproduksi konvensional (yang lama). Pada sistim produksi yang baru, semua hasil samping tidak dianggap sebagai limbah, tetapi sebagai spent resources atau sumberdaya yang telah digunakan untuk suatu tujuan tertentu menjadi suatu komoditas yang telah direncanakan sesuai dengan proses yang telah diketahui dari sumberdaya apa menjadi produk apa.

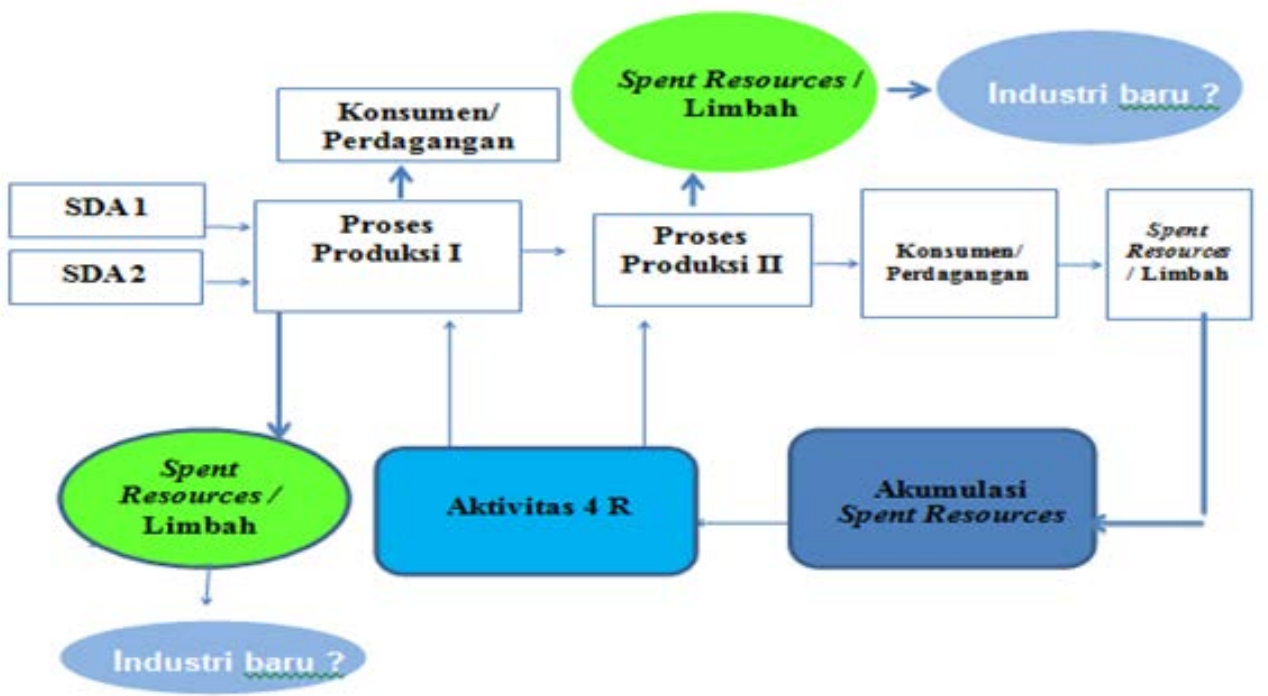

Gambar 2. Siklus Eco-Economic Decoupling 
Sedangkan hasil sampingnya akan dilakukan pengembangan lanjut apakah dapat dijadikan suatu sumberdaya dengan yang sama atau klasifikasi lain.

Dari suatu proses produksi misalkan ada produk samping, dalam konsep lama produk samping tersebut dibuang, sedang dalam konsep baru maka produk samping akan dianggap sebagai suatu resources baru dan tidak lalu segera dibuang, demikian pula pada proses-proses berikutnya. Setiap ada hasil samping, pada tiap tahap proses, akan dilakukan penelitian untuk mengetahui tentang unsur-unsur atau elemen-elemen material yang ada atau tertinggal dalam kandungan produk samping tersebut. Setelah diketahui unsur-unsurnya baru dapat dirancang tentang bagaimana pemanfaatan lanjutnya. Demikian juga pada proses-proses selanjutnya termasuk setelah melewati tahap penggunaan oleh konsumen produk tersebut.

Dengan demikian eco-economic decoupling pada dasarnya terdapat tiga unsur, yakni: ${ }^{7)}$

1. Mengurangi tekanan terhadap lingkungan dan sumberdaya.

2. Meningkatkan pertumbuhan ekonomi

3. Adanya pemanfaatan inovasi di bidang ilmu pengetahuan dan teknologi dalam pemanfaatan spent resources agar dapat menggerakkan perekonomian.

Kajian terdahulu diantaranya adalah dilakukan oleh Haryati dan Munandar ${ }^{10)}$ tentang pemanfaatan limbah pembuatan abon ikan bandeng di Kabupaten Serang. Penerapan konsep zero waste melalui optimalisasai pemanfaatan limbah pada pengolahan abon ikan dapat dilakukan baik terhadap limbah cair maupun limbah padat. Pemanfaatan limbah cair berupa air pencucian dan air perebusan yang mengandung protein terlarut dapat digunakan menjadi bahan tambahan dalam membuat pakan ternak bebek berbentuk pasta dan flavor produk. Pemanfaatan limbah padat berupa tulang dan duri ikan dapat digunakan menjadi tepung tulang ikan, limbah kepala ikan dapat diolah menjadi kerupuk berkalsium, dan pemanfaatan terhadap isi perut dan insang dapat digunakan sebagai bahan pembuatan silase ikan atau produk bekasang. Limbah padat berupa kulit ikan bandeng dapat diolah menjadi crispy kulit ikan. Kajian lain dilakukan oleh Usman Malik ${ }^{11)}$ tentang potensi produk sampingan dari produksi kayu. Potensi bahan baku kayu yang belum termanfaatkan jumlahnya sebesar 2,03 juta m3 /th untuk industri pengolahan kayu. Limbah dari industri pengolahan kayu dapat dimanfaatkan menjadi arang serbuk dengan teknologi kiln semi kontinyu, briket arang, arang aktif, arang kompos, soil conditioning Hasil sosialisasi arang kompos dapat menghemat pengeluaran bulanan keluarga dan lebih menyuburkan lahan tanah. Namun demikian sulit untuk mengubah pola budaya yang sudah biasa dilakukan oleh masyarakat.

Kajian-kajian terdahulu belum memperkenalkan konsep spent resources tapi masih berbicara tentang limbah. Kajian ini mencoba memperkenalkan paradigm baru terkait ecoeconomic decoupling dan spent resources. Selama ini yang biasa kita kenal sebagai limbah ternyata belum tentu limbah karena dengan sentuhan teknologi limbah tersebut bisa menjadi sumberdaya yang bisa digunakan kembali untuk kegiatan ekonomi. Kajian ini penting dilakukan dikarenakan konsep spent resources belum banyak dikenal oleh masyarakat. Selain itu, dalam kajian terdahulu tidak sekaligus menyinggung tentang kebijakan pemerintah dalam hal penanganan spent resources.

Rumusan masalah kajian ini adalah bagaimana potensi spent resource yang ada di Provinsi Jawa Tengah, apa saja permasalahan dalam pemanfaatan spent resources di Provinsi Jawa Tengah, dan bagaimana dampak pemanfaatan spent resources di Provinsi Jawa Tengah.

\section{METODE}

Kajian ini dilaksanakan Tahun 2014 dengan mengambil lokasi di Provinsi Jawa Tengah. Jawa Tengah dipilih sebagai lokasi kajian dengan pertimbangan sebagai tahap awal kajian mengambil lokasi salah satu provinsi di Pulau Jawa sebagai Pulau dengan kepadatan penduduk yang tinggi dengan konsentrasi kebutuhan energi yang tinggi sehingga akan berhubungan dengan ketersediaan spent resources. Kajian dilaksanakan menggunakan pendekatan kualitatif dengan metode dekriptif. Data yang dikumpulkan dalam kajian ini ada 2 (dua) jenis, yaitu data primer dan data sekunder. Data primer diperoleh dari hasil wawancara langsung dengan aparat Bappeda, Badan Lingkungan Hidup, dan Badan Penelitian dan Pengembangan Daerah. Sedangkan data sekunder diperoleh dari studi pustaka dan data penunjang yang relevan dengan kajian.

\section{HASIL DAN PEMBAHASAN}

\section{Potensi Eco-Economic Decoupling di Provinsi Jawa Tengah}

Dalam kamus besar bahasa Indonesia, potensi berarti kemampuan yang mempunyai kemungkinan untuk dikembangkan; kekuatan; kesanggupan; daya 8). Potensi merupakan segala kemampuan yang dimiliki daerah yang bisa dimanfaatkan untuk tujuan tertentu. Potensi eco-economic decoupling yang dimaksud disini adalah mulai dari kebijakan/ regulasi, kondisi ketersediaan spent resources dan kegiatan yang selama ini sudah dilaksanakan.

1) Kebijakan/ Regulasi

Kebijakan/ regulasi terkait eco-economic decoupling yang diacu dari daerah merupakan kebijakan dari pemerintah pusat dan kebijakan dari pemerintah daerah sendiri. Kebijakan dari pemerintah pusat terkait pembangunan dengan memperhatikan faktor lingkungan merupakan 
amanat Undang-Undang No 23 tahun 2014 tentang Pemerintahan Daerah dan secara teknis regulasi yang lain diantaranya adalah Undang-Undang No 32 tahun 2009 tentang Perlindungan dan Pengelolaan Lingkungan Hidup, Peraturan Pemerintah No 19 Tahun 1999 tentang Pengendalian Pencemaran dan/ atau Perusakan Laut, Peraturan Pemerintah No 82 Tahun 2001 tentang Pengelolaan Kualitas Air dan Pengendalian Pencemaran Air.

UU 23 Tahun 2014 tentang pemerintahan daerah Pasal 262 secara eksplisit menyebutkan bahwa Rencana pembangunan Daerah dirumuskan secara transparan, responsif, efisien, efektif, akuntabel, partisipatif, terukur, berkeadilan, dan berwawasan lingkungan. Yang dimaksud dengan "berwawasan lingkungan” adalah untuk mewujudkan kehidupan adil dan makmur tanpa harus menimbulkan kerusakan lingkungan yang berkelanjutan dalam mengoptimalkan manfaat sumber daya alam dengan cara menserasikan aktivitas manusia dengan kemampuan sumber daya alam yang menopangnya.

Beberapa kebijakan terkait pengelolaan lingkungan dan pemanfaatan spent resources seperti adanya Peraturan Daerah Provinsi Jawa Tengah Nomor 3 Tahun 2014 tentang Pengelolaan Sampah di Jawa Tengah, Perda Provinsi Jateng No. 20 Tahun 2003 tentang Pengelolaan Kualitas Air dan Pengendalian Pencemaran Air Lintas Kabupaten/ Kota, Perda Provinsi Jateng No. 5 Tahun 2007 tentang Pengendalian Lingkungan Hidup, dan Perda Provinsi Jateng No. 5 Tahun 2012 tentang Perubahan Atas Perda Prov. Jateng No 10 Tahun 2004 tentang Baku Mutu Air Limbah.

Meskipun belum secara khusus belum terdapat peraturan daerah terkait kegiatan ecoeconomic decoupling, namun peraturan-peraturan yang sudah ada di atas sejalan dengan prinsip-prinsip dalam melaksanakan kegiatan eco-economic decoupling. Seperti contoh bahwa Peraturan Daerah Provinsi Jawa Tengah Nomor 3 Tahun 2014 tentang Pengelolaan Sampah di Jawa Tengah yang bertujuan untuk meningkatkan upaya pengurangan sampah melalui teknologi 3 R (Reduce, Reuse, Recycle). Adanya peraturan ini telah semakin mendorong kebijakan penanganan limbah baik padat maupun cair di Jawa Tengah yang telah dilaksanakan sejak tahun 1998 agar dapat dimanfaatkan dan menjadi komoditas yang mempunyai nilai ekonomi dan bermanfaat bagi masyarakat sekaligus mengurangi dampak pencemaran/kerusakan terhadap lingkungan. Tujuan adanya kebijakan dan kegiatan yang sudah berjalan telah mendukung prinsip kegiatan ecoeconomic decoupling yaitu pengurangan tekanan terhadap lingkungan dan sumberdaya, mendorong peningkatan kegiatan ekonomi melalui pemanfaatan spent resources, dan adanya pemanfaatan teknologi dalam pemanfaatan spent resources agar dapat bernilai kembali.

\section{2) Ketersediaan Spent Resources}

Spent resources merupakan istilah baru yang digunakan agar tidak memandang limbah sebagai sesuatu yang sudah tidak bermanfaat dan dibuang, melainkan memandang sebagai sumberdaya yang telah tergunakan yang melalui sentuhan teknologi dapat dipergunakan kembali dalam proses produksi yang bernilai ekonomi seperti yang sudah digambarkan pada gambar2.

Gambaran kondisi ketersediaan spent resources di Provinsi Jawa Tengah diantaranya dapat digambarkan sebagai berikut ${ }^{9)}$ :

\section{$\underline{\text { Sektor Sampah }}$}

Jumlah timbulan sampah perkotaan adalah 8.883 ton/hari dan pedesaan 5.273 ton/hari, sehingga total jumlah timbunan sampah adalah sebesar 14.156 ton/hari. Sedangkan jumlah sampah yang terangkut sebesar 68 \% dari total timbunan sampah atau 9.626 ton/hari yang ditampung di 35 TPA Kabupaten/Kota se Jawa Tengah. Pengelolaan sampah di TPA se Jawa Tengah adalah sebagai berikut : 1) TPA dengan kedalaman lebih dari 5 meter dan tertutup sebanyak 15.TPA yang menampung 55.136.100 ton sampah, 2) TPA dengan kedalaman lebih dari 5 meter dan tidak tertutup sebanyak 6 TPA yang menampung 4.377.500 ton sampah, dan 3) TPA dengan kedalaman kurang dari 5 meter dan tidak tertutup sebanyak 10 TPA yang menampung 5.461.038 ton sampah. Sedangkan jumlah sampah yang tidak terangkut dengan jumlah 4.530 ton/hari kondisinya adalah sebagai berikut :

1) Dikelola oleh masyarakat dengan pengomposan sebesar $10 \%$ atau $0,1 \times 4.530$ ton/hari $=453$ ton/hari;

2) Dibakar sebesar $5 \%$ atau $0.05 \times 4.530$ ton/hari $=$ 226.5 ton/hari

3) Dibuang sembarangan sebesar $5 \%$ atau $0,05 \mathrm{X}$ 4.530 ton/hari $=226.5$ ton/hari

\section{$\underline{\text { Sektor Industri }}$}

Sektor industri yang tumbuh dan berkembang di Jawa Tengah dibagi menjadi empat kategori, yaitu : industri besar, industri sedang, industri kecil, industri rumah tangga. Jumlah perusahaan yang masuk kategori industri besar dan sedang pada tahun 2009 tercatat sebanyak 4.213 unit perusahaan. Berdasarkan pada produk yang dihasilkan industri, maka jumlah total limbah cair yang dikeluarkan industri se Jawa Tengah tahun 2010 sejumlah 1.159.592.400 m3.

\section{$\underline{\text { Sektor Limbah Cair }}$}

Industri yang berpotensi mengeluarkan emisi GRK dari limbah cair yang dihasilkan adalah industri makanan dan minuman. Di Jawa Tengah terdapat 2.411 usaha yang diperkirakan menghasilkan limbah cair rata- rata sebesar $5 \mathrm{~m}^{3} /$ hari atau mencapai 1.159.592.400 $\mathrm{m}^{3}$ per tahun. Selain dari limbah industri, emisi GRK juga dihasilkan dari pengelolaan 
limbah domestik. Dengan jumlah penduduk Jawa Tengah sebesar 32.382.657 jiwa, limbah cair yang dihasilkan setara dengan 472.787 ton BOD pada tahun 2010. Sementara itu, limbah domestik yang dihasilkan sebesar 154 liter/org/hari, sehingga total limbah cair domestik yang dihasilkan oleh pemukiman di Jawa Tengah adalah 886, 4 juta $\mathrm{m}^{3}$.

\section{Sektor Pertanian}

Selama kurun waktu 20 tahun, Provinsi Jawa Tengah menjadi salah satu penyangga pangan nasional terutama beras. Luas lahan tanaman padi di Jawa Tengah adalah 1.801.397 ha dengan produktivitas $56,13 \mathrm{kw} / \mathrm{ha}$.

\section{Sektor Peternakan}

Produk andalan Jawa Tengah pada sektor peternakan antara lain daging, telur dan susu. Sektor peternakan juga mempunyai potensi pencemaran lingkungan berupa limbah kotoran ternak

\section{$\underline{\text { Sektor Perikanan }}$}

Sektor perikanan meliputi kegiatan perikanan laut dan perikanan darat. Perikanan darat terdiri dari usaha budidaya (tambak, sawah, kolam, karamba) dan perairan umum (waduk, telaga dan rawa). Produksi yang dihasilkan dari kegiatan perikanan pada tahun 2010 di Jawa Tengah mencapai total 421.000 ton dengan nilai 3.566,9 milyar rupiah, sedangkan untuk produksi ikan yang dihasilkan dari budidaya perikanan di darat adalah 208.433 ton. Perikanan darat biasanya menggunakan kapur yang dapat menghasilkan emisi gas rumah kaca, adapun jumlah kapur yang digunakan pada kegiatan perikanan di darat pada tahun 2010 mencapai 150.000.000 gram atau 150 ton

\section{3) Pemanfaatan Spent Resources}

Secara umum daerah belum melakukan pemetaan terkait dengan pemanfaatan spent resources. Tetapi terkait kegiatan SKPD ada yang sudah melakukan pemetaan. Seperti setiap tahun BLH Prov. Jateng menghimpun data isian terkait dengan pelaksanaan program Adipura (kota Bersih), dari data tersebut dapat diketahui potensi timbulan sampah serta upaya 3R yang telah dilakukan oleh Kabupaten/Kota Se Jawa Tengah.

Beberapa pemanfaatan spent resources yang sudah dilakukan di daerah diantaranya adalah:

a. Pemanfaatan limbah tahu di Kota Pekalongan menjadi biogas.

b. Kompos dari sampah, kerajinan dari plastik, biogas dari kotoran ternak.

c. Sampah pertanian menjadi pupuk organik, limbah tahu menjadi energi/ gas, sampah menjadi energi, sampah 3R menjadi bank sampah

d. Pemanfaatan enceng gondok di rawa pening sudah menjadi produk sandal hotel, dan bisa dijadikan makanan ternak karena mengandung omega 3 yang tinggi. e. pengembangan DME (Desa Mandiri Energi) dengan memanfaatkan sampah di desa, pengelolaan limbah tahu dan ternak menjadi energi.

f. Sektor swasta ada PT. Sidomuncul yang sudah mengekspor pupuk yang berasal dari limbah produksi.

g. Ada pabrik tepung ikan, dan sisik ikan hasil limbah yang dikerjakan oleh swasta Murni di Tegalsari.

Di lihat dari berbagai kegiatan yang sudah berjalan di atas, secara sengaja ataupun tidak dapat dikatakan bahwa telah ada kegiatan eco-economic decoupling di Provinsi Jawa Tengah. Hal ini dapat dilihat dari adanya pengurangan tekanan terhadap sumberdaya dan lingkungan dengan pemanfaatan sumberdaya yang telah tergunakan (spent resources), adanya pemanfaatan tekhnologi, dan adanya manfaat ekonomi kembali dari pemanfaatan sumberdaya yang telah tergunakan (spent resources).

Beberapa Kementerian/Lembaga serta SKPD terkait yang terlibat dalam eco-economic decoupling di Jawa Tengah adalah Kementerian Lingkungan Hidup, Kementerian Perindustrian, Bappeda Prov. Jateng, Dinas ESDM Prov. Jateng, Dinas Perindustrian dan Perdagangan Prov. Jateng, Kemen PU, dan BPPT. Keterpaduan kebijakan dan program dari pihak-pihak terkait dalam pemanfaatan spent resources di daerah diwujudkan melalui SKPD terkait selalu melakukan rapat-rapat koordinasi yang biasanya dikoordinir oleh BAPPEDA guna memadukan program terkait lingkungan. Tetapi selama ini belum ada khusus eco-economic decoupling dalam kebijakan dan programprogramnya.

Upaya daerah dalam rangka mengupayakan keterpaduan kebijakan dan program dari pihak-pihak terkait dalam pemanfaatan spent resorces di daerah adalah SKPD terkait telah mempunyai jadwal reguler tahunan dalam penyelenggaran pertemuan atau pameran dalam rangka peningkatan pemanfaatan limbah maupun pameran gelar teknologi lingkungan guna mensosialisasikan temuan-temuan baru dan produk-produk hasil pemanfaatan limbah, koordinasi lintas sektor antar SKPD terkait yang diimplementasikan dalam penyusunan program/kegiatan dan anggaran. Selain itu terdapat berbagai forum dalam upaya keterpaduan kebijakan seperti:

a. Forum Pengembangan Ekonomi dan Sumber Daya Jawa Tengah (FPESD) yang didirikan berdasarkan Surat Keputusan (SK) Gubernur Jawa Tengah No. 500.05/34/2008. Keanggotaan FPESD Jawa Tengah terdiri dari 90 instansi baik sektor Pemerintah, KADIN, pelaku usaha, FEDEP, Pemerintah Kab./Kota, dan unsur-unsur terkait dalam pengembangan UKM. Keanggotaan ini difokuskan pada formulasi masukan yang ditujukan pada Gubernur Jawa Tengah. Dalam periode 2008-2013, berdasarkan SK Ketua 
FPESD tentang Pembentukan Kelompok Kerja (POKJA) FPESD Jawa Tengah, secara operasional POKJA DFPESD Jawa Tengah dibagi atas 7 (tujuh) POKJA. yaitu: POKJA Industri dan Perdagangan, POKJA Pariwisata dan Kebudayaan, POKJA Pertanian dan Kawasan Pertanian, POKJA Business Development Services (BDS) dan Permodalan, POKJA Pengembangan Teknologi dan Inovasi, POKJA Iklim Usaha Kondusif, POKJA FEDEP (Forum for Economic Development and Employment Promotion). Pengelompokan di atas ditujukan agar lebih fokus dan mampu memberikan saran, pertimbangan dan alternatif masukan sebagai bahan pertimbangan penyusunan kebijakan program yang sinergis.

b. Forum for Economic Development and Employment Promotion (FEDEP) beranggotakan orang - orang dari sektor Pemerintah di tingkat Kab./Kota, pelaku usaha daerah, stakeholder terkait termasuk anggota dari klaster, KADIN, dan asosiasi-asosiasi. FEDEP merupakan forum dialog untuk pengembangan ekonomi dan perluasan lapangan kerja di daerah. Forum ini adalah forum kemitraan terlembaga bagi para pelaku ekonomi di daerah yang relevan, bertujuan untuk mempercepat pembangunan ekonomi daerah melalui pemberian saran dan arahan kebijakan tentang usaha-usaha/kegiatan bersama berbasis potensi lokal. Dalam pelaksanaan kegiatannya, FEDEP memfasilitasi organisasi dan individu dari sektor pemerintah maupun swasta untuk mensinergikan program PEL (Pengembangan Ekonomi Lokal) di daerah agar lebih optimal, terpadu dan berkelanjutan sesuai dengan kebutuhan masyarakat. Program Pengembangan Ekonomi Lokal (PEL) Jawa Tengah telah dilaksanakan sejak Tahun 2001.

Selain kementerian/ lembaga dan SKPD pemerintah yang terlibat dalam pemanfaatan spent resorces adalah swasta dan masyarakat. Beberpa industri di Jawa Tengah yang masuk bidang Agro seperti industri gula, makanan dan minuman telah melakukan uji coba pemanfaatan limbah yang dihasilkan dari proses pengolahan air limbah menjadi bahan pupuk organik. Sektor swasta ada PT. Sido Muncul yang sudah mengekspor pupuk yang berasal dari limbah produksi. Ada pemanfaatan limbah sisik ikan yang dilakukan oleh sektor swasta di Tegalsari. Pemda hanya menyediakan lahan. Sementara keterlibatan masyarakat dalam pemanfaatan spent resources di daerah terlihat pada pendirian Bank Sampah di Jawa Tengah yang difasilitasi oleh BLH Prov. Jateng sebagai pengembangnya adalah kelompok-kelompok masyarakat baik itu kelompok peduli lingkungan maupun kelompok Ibu-ibu PKK. Masyarakat menjadi pihak yang menggunakan hasil spent resources.

Sumber pendanaan pemanfaatan spent resources di daerah sebagian besar dari APBD
Provinsi Jawa Tengah dan sebagian lain dari pemerintah, swasta dan swadaya masyarakat. Danadana tersebut masih tersebar di SKPD lain sesuai Tugas Pokok dan Fungsi SKPD terkait.

Ketersediaan bahan baku dari pemanfaatan spent resources banyak tersedia karena merupakan bahan yang sudah tidak dipergunakan dan terkait dengan kegiatan manusia, misalnya limbah plastik, kertas, sampah daun, limbah cair industri tahu, kotoran ternak. Saat ini masih ada potensi spent resources tetapi belum dimanfaatkan. Potensi tersebut masih cukup banyak karena terkait dengan jumlah penduduk, semakin meningkat/padat jumlah penduduk semakin banyak yang dapat dimanfaatkan.

a. Permasalahan dalam Pemanfaatan Spent $R$

Dalam pelaksanaannya, masih terdapat permasalahan dalam pemanfaatan spent resources di daerah. Permasalahanpermasalahan tersebut terkait dengan kebijakan/ regulasi, kelembagaan, pembiayaan, koordinasi kebijakan dan program serta masalah lainnya.

Dari sisi kebijakan/regulasi misalnya belum ada kebijakan khusus yang mengatur spesifik tentang eco-economic decoupling dan pemanfaatan spent resources. Dari sisi kelembagaan, pemanfaatan /pengolahan limbah menjadi barang yang bernilai ekonomis membutuhkan organisasi kemasyarakatan sebagai pengelola agar ada keberlanjutan program. Selama ini belum ada kelembagaan yang mengatur, khususnya untuk eco-economic decoupling yang ada selama ini hanya kelembagaan yang dibentuk sesuai dengan kebutuhan.

Dari sisi pembiayaan permasalahan biasanya terjadi kalau tidak ada tempat/lahan untuk membangun Instalasi pemanfaatan limbah serta belum ada organisasi pengelola yang dapat menjamin keberlangsungan operasional pemanfaatan limbah. Beberapa kegiatan membutuhkan anggaran yang besar, sehingga perlu ada fasilitasi dari pusat termasuk juga dari kewenangan yang ada. Dari sisi koordinasi kebijakan dan program selama ini masih belum ada permasalahan yang berarti karena sudah sesuai dengan kewenangannya, tetapi ada beberapa hal yang memang tidak memahami arti dan manfaat eco-economic decoupling.

Selain berbagai permasalahan di atas, beberapa permasalahan lain dalam pemanfaatan spent resources diantaranya adalah:

1) Belum adanya pasar khusus untuk dapat menerima produk-produk yang berasal dari pemanfaatan spent resources agar tercapai keberlanjutan serta tercapai peningkatan kualitas lingkungan

2) Kelemahan pada diseminasi hasil kelitbangan yang dapat bermanfaat bagi pemanfaatan spent resources. 
3) Perguruan tinggi seringkali tidak siap dalam praktek, hanya kaya teori. Sempat ada forum link and match mengundang pengusaha, perguruan tinggi dan pemerintah dimana perguruan tinggi diharapkan menyiapkan inovasi agar ditangkap oleh pengusaha. Tapi dalam perjalanan ternyata perguruan tinggi belum siap.

4) Seringkali bantuan yang diberikan pemerintah tidak komperehensif menuntaskan permasalahan dari A sampai $\mathrm{Z}$, padahal masyarakat belum siap untuk mandiri. Seringkali program pemerintah berhenti sebelum masyarakat mandiri

5) Masih terdapat permasalahan sinergitas antar SKPD dimana output hanya terbatas pada tupoksi masing-masing SKPD. SKPD belum link and match dalam merencanakan program. Dalam hal ini tugas Bappeda sangat penting. Ego sektoral perlu dihilangkan. Komitmen kepala daerah dan jajaran pimpinan SKPD sangat diperlukan.

6) Masalah limbah B3 dan sampah di TPA perlu peran pemerintah pusat. Hal ini karena skalanya besar, butuh inovasi yang tinggi, biaya yang besar, dan koordinasi lintas sektor yang luas.

7) Masyarakat seringkali masih kesulitan mempertanggungjawabkan kegiatannya sesuai aturan akuntansi pemerintahan sehingga berpotensi menimbulkan masalah administrasi.

8) Terdapat beberapa kasus pemanfaatan limbah. Di Pati ada pengolahan batok kelapa dibakar menjadi briket. Tetapi kegiatan ini menimbulkan masalah ISPA bagi masyarakat sekitar. Di Tegal ada pengolahan B3. Secara ekonomi menguntungkan tapi dalam jangka panjang berdampak pada penurunan mental masyarakat dan secara fisik masyarakat menjadi kerdil. Dari kasus ini kita harus belajar bahwa manfaat yang diukur tidak hanya dari aspek ekonomi tapi dampak lainnya.

9) Dampak Pemanfaatan Spent Resources di daerahPemanfaatan spent resources berdampak pada banyak hal diantaranya adalah pada ketersediaan sumberdaya, kelestarian lingkungan, masyarakat, pemda, sektor swasta, dan perekonomian daerah.

Terhadap ketersediaan sumberdaya berdampak pada pengurangan jumlah polutan yang dibuang ke lingkungan sehingga kualitas lingkungan tidak menurun. Selain itu cukup memberikan harapan terhadap efisiensi pemanfaatan sumber daya. Dampak kegiatan eco-economic decoupling terhadap kelestarian lingkungan menjadikan lingkungan tidak tercemar sehingga daya dukung lingkungan terhadap aktivitas manusia dapat dipertahankan pada level yang baik, selain itu cukup memberikan harapan terhadap keberlanjutan dan kelestarian lingkungan ke depan.

$$
\text { Dampak kegiatan eco-economic }
$$
decoupling terhadap masyarakat adalah bahwa pemanfaatan spent resources menjadi barang yang mempunyai nilai ekonomis dapat menambah penghasilan masyarakat sekaligus mengurangi pencemaran/kerusakan lingkungan. Selain dampak positif terhadap masyarakat, kegiatan pemanfaatan spent resources juga memberikan dampak negatif. Terdapat beberapa kasus pemanfaatan limbah. Di Pati ada pengolahan batok kelapa dibakar menjadi briket. Tetapi kegiatan ini menimbulkan masalah ISPA bagi masyarakat sekitar. Di Tegal ada pengolahan B3. Secara ekonomi menguntungkan tapi dalam jangka panjang berdampak pada penurunan mental masyarakat dan secara fisik masyarakat menjadi kerdil. Dari kasus ini kita harus belajar bahwa manfaat yang diukur tidak hanya dari aspek ekonomi tapi dampak lainnya.

Dampak kegiatan eco-economic decoupling terhadap pemerintah daerah adalah bahwa program-program Pemerintah terkait dengan Pengendalian Pencemaran/Kerusakan lingkungan dapat berjalan sinergis dengan kegiatan masyarakat termasuk peningkatan ekonomi masyarakat. Akan membantu terhadap manajemen pengelolaan sumberdaya dan menangani permasalahan limbah serta peningkatan kesejahteraan masyarakat.

Dampak kegiatan eco-economic decoupling terhadap sektor swasta adalah dapat membantu efisiensi biaya produksi dengan memakai energi hasil pemanfaatan spent resources sekaligus mendatangkan keuntungan dari produksi hasil pemanfaatan spent resources.

Dampak kegiatan eco-economic decoupling terhadap perekonomian daerah adalah mampu meningkatkan perekonomian daerah meskipun masih belum terlihat secara signifikan namun telah mampu membuka lapangan pekerjaaan pada masyarakat kelas bawah untuk memanfaatkan barang-barang yang terbuang menjadi komoditas yang bernilai ekonomi. Kegiatan ini diharapkan akan mendorong peningkatan perekonomian dan pengurangan limbah dari pemnafaatan SDA.

\section{KESIMPULAN}

1. Terdapat potensi pemanfaatan spent resources sebagai bagian dari kegiatan eco-economic decoupling di Provinsi Jawa Tengah. Meskipun regulasi, dan kegiatan yang ada belum secara tersurat menyebutkan perihal eco-economic 
decoupling, tetapi secara sengaja ataupun tidak sudah terdapat kegiatan pemanfaatan spent resources yang sudah melaksanakan prinsipprinsip eco-economic decoupling. Spent resources selalu tersedia karena berhubungan dengan aktivitas manusia. Sudah terdapat forumforum yang bisa dijadikan sebagai prasarana keberlanjutan kegiatan eco-economic decoupling. Namun demikian potensi tersebut masih perlu dioptimalkan karena masih terdapat beberapa kendala dalam pemanfaatan.

2. Permasalahan dalam pemanfaatan spent resources antara lain:

a. Kurangnya pengetahuan dan pemahaman tentang konsep spent resources dan ecoeconomic decoupling diantara para stakeholder.

b. Belum ada kebijakan khusus tentang ecoeconomic decoupling.

c. Belum optimalnya peran Pemerintah Daerah dalam pemanfaatan spent resources.

d. Belum adanya sinergitas program dan kegiatan dalam mendukung pemanfaatan spent resources.

e. Masih terdapatnya beberapa kasus pemanfaatan spent resources yang menguntungkan secara ekonomi tetapi berdampak negatif terhadap kesehatan.

f. Daerah masih mengalami kendala pembiayaan untuk penanganan spent resources dalam skala besar.

3. Pemanfaatan spent resources memberikan dampak positif yaitu pengurangan tekanan terhadap lingkungan dan sumberdaya alam, peningkatan lapangan pekerjaan dan pendapatan masyarakat.

4.

Saran yang dapat disampaikan dalam penelitian ini:

1. Perlu peningkatan pengetahuan dan pemahaman tentang eco-economic decoupling diantara para stakeholder melalui kegiatan sosialisasi.

2. Perlu penguatan komitmen pemerintah dan pemerintah daerah terhadap pemanfaatan spent resources sebagai kegiatan eco-economic decoupling. Diantara bentuk komitmen pemerintah dan pemerintah daerah adalah mengupayakan agar Eco-economic Decoupling menjadi salah satu program pembangunan daerah, dan tertuang dalam dokumen perencanaan pembangunan daerah.

3. Perlunya kebijakan khusus tentang eco-economic decoupling di tingkat Pusat dan Daerah.

4. Perlu pemetaan potensi eco-economic decoupling di daerah.

5. Sinergitas kebijakan terkait eco-economic decoupling di tingkat Pusat dan antara Pusat dan Daerah.

6. Perlu optimalisasi pemanfatan jaringan/ forumforum yang sudah terbentuk di daerah yang melibatkan stakeholder Pemerintah Daerah, akademisi, pengusaha dan masyarakat untuk kegiatannya perlu diarahkan pula untuk mendukung eco-economic decoupling.

7. Perlu kajian lebih mendalam terkait pemanfaatan spent resources dalam mendukung kegiatan ecoeconomic decoupling. Perlu perhitungan secara spesifik mengenai perhitungan potensi spent resources, dampak pengurangan terhadap tekanan bagi lingkungan dan sumber daya, dampak manfaat secara ekonomi dari pemanfaatan spent resources, dan model teknologi/ inovasi yang digunakan dalam pemanfaatan spent resources.

\section{Daftar Pustaka}

Azis Nur Bambang, 2000. Bahan Kuliah Ekonomi Sumberdaya Perikanan Untuk Program S-2. Magister Manajemen Sumberdaya Pantai. Program Pasca Sarjana Universitas Diponegoro .Semarang.

Kajian Indonesia Energi Outlook. Pusat Data Dan Informasi Energi Dan Sumber Daya Mineral Kementerian Energi Dan Sumber Daya Mineral. 2012

Proyeksi Kebutuhan Dan Penyediaan Energi Listrik Di Jawa Tengah Menggunakan Perangkat Lunak Leap, R. Kakka Dewayana P1, Dr. Ir. Hermawan, DEA2, Karnoto, S.T., M.T.3. Jurusan Teknik Elektro Fakultas Teknik Universitas Diponegoro

Http://Www.Tempo.Co/Read/News/2012/09/27/206432 233/Ribuan-Industri-Jateng-Hasilkan-LimbahBerbahaya Diakses Pada 9 Januari 2014

Sunaryo Prasetyo Dan Titiresmi. 2014. Eco-Economic Decoupling. Disampaikan Dalam FGD Pemetaan Sumber-Sumber Eco-Economic Decoupling dalam rangka Mengurangi Tekanan terhadap Lingkungan dan Sumberdaya di Daerah. Jakarta

Sunaryo Prasetyo i. 2014. Eco-Economic Decoupling. Disampaikan Dalam Seminar Kajian "Pemanfaatan Eco-Economic Decoupling sebagai Bahan Perumusan Kebijakan”. Jakarta

Pusat Libang Pembangunan Dan Keuangan Daerah Badan Litbang Kementerian Dalam Neger. 2014. Pemanfaatan Eco-Economic Decoupling Sebagai Bahan Perumusan Kebijakan. Laporan Akhir. Jakarta

Badan bahasa.Kemdikbud.Go.Id/Kbbi

http://www.sekretariat-rangrk.org/beranda/102bahasa/status-provinsi/115-jateng, diakses 26 Januari 2015

Sakinah Haryati dan Aris Munandar. Penerapan Konsep Zero Waste Pada Pengolahan Abon Ikan Bandeng Jurnal Perikanan dan Kelautan Vol. II No. 2: 127-130. Desember 2012. Jurusan Perikanan, Fakultas Pertanian, Universitas Sultan Ageng Tirtayasa.

Usman Malik. Alternatif Pemanfaatan Limbah Industri Pengolahan Kayu Sebagai Arang Briket. Jurnal Aptek Vol. 5 No. 1Januari2013. 
